\title{
MENINGKATKAN KETERAMPILAN BERPIKIR KRITIS MELALUI MODEL PROBLEM BASED LEARNING BERBASIS LITERASI SAINS
}

\author{
Indah Dwi Wijayanti ${ }^{1}$, Badarudin ${ }^{2}$, Santhy Hawanti ${ }^{3}$ \\ ${ }^{123}$ Universitas Muhammadiyah Purwokerto \\ ${ }^{1}$ indahdwiwijayanti6@gmail.com ${ }^{2}$ badarudinbdg@gmail.com ${ }^{3}$ santhyhawanti@ump.ac.id
}

\begin{abstract}
This study aims to improve students' critical thinking skills through the application of problem-based learning models based on scientific literacy in class IV. This type of research is Classroom Action Research (CAR). The class action research was carried out in 3 cycles, each cycle consisting of two meetings. This research consisted of the stages of planning, implementation, observation, evaluation and reflection. The subjects of this study were the IVB grade students of SDN 1 Tinggarjaya, amounting to 11 male students and 15 female students. Data collection tools use critical thinking skills tests, teacher activity sheets and student activity sheets. The results of the critical thinking skills test are based on five indicators of students' critical thinking skills that are carried out at each end of the meeting. The results of this class action research show that learning using the problem-based learning model based on scientific literacy can improve students' critical thinking skills on the theme of 7 Beautiful Diversity in My Country in class IVB SDN 1 Tinggarjaya. Students experience an increase in each cycle, namely, in cycle 1 an average score of 1.95 is obtained with unfavourable criteria, cycle 2 obtains an average score of 2.57 with unfavourable criteria and cycle 3 obtains an average score of 3.04 with good criteria.
\end{abstract}

Keywords: Critical Thinking Skills; Problem Based Learning; Scientific Literacy

\begin{abstract}
Abstrak
Penelitian ini bertujuan untuk meningkatkan keterampilan berpikir kritis peserta didik melalui penerapan model Problem Based Learning berbasis literasi sains di kelas IV. Jenis penelitian ini adalah Penelitian Tindakan Kelas (PTK). Penelitian tindakan kelas tersebut dilaksanakan dalam 3 siklus, masing-masing siklus yang terdiri dari dua pertemuan Penelitian ini terdiri dari tahapan perencanaan, pelaksanaan, observasi, evaluasi dan refleksi. Subjek penelitian ini adalah peserta didik kelas IVB SDN 1 Tinggarjaya yang berjumlah 11 peserta didik laki-laki dan 15 peserta didik perempuan. Alat pengumpulan data menggunakan tes keterampilan berpikir kritis, lembar aktivitas guru dan lembar aktivitas peserta didik. Hasil tes keterampilan berpikir kritis berdasarkan lima indikator keterampilan berpikir kritis peserta didik yang dilakukan pada setiap akhir pertemuan. Hasil penelitian tindakan kelas ini menunjukkan bahwa pembelajaran menggunakan model Problem Based Learning berbasis literasi sains dapat meningkatkan keterampilan berpikir kritis peserta didik pada tema 7 Indahnya Keragaman di Negeriku pada kelas IVB SDN 1 Tinggarjaya. Peserta didik mengalami peningkatan di setiap siklusnya yaitu pada siklus 1 diperoleh skor rata-rata 1,95 dengan kriteria tidak baik, siklus 2 memperoleh skor rata-rata 2,57 dengan kriteria kurang baik dan siklus 3 memperoleh skor rata-rata 3,04 dengan kriteria baik.
\end{abstract}

Kata Kunci: Keterampilan Berpikir Kritis; Problem Based Learning; Literasi Sains

\begin{tabular}{llll}
\hline Received & $: 2020-05-02$ & Approved & $: 2020-06-01$ \\
Reviesed & $: 2020-05-29$ & Published & $: 2020-07-31$ \\
\hline
\end{tabular}

cc) (†) (D) Jurnal Cakrawala Pendas is licensed under a Creative Commons AttributionEY SA ShareAlike 4.0 International License.

\section{Pendahuluan}

Pendidikan memiliki peran penting dalam era globalalisai. Pendidikan menjadikan setiap orang dapat menyikapi perubahan di era globalisai ini. Pemerintah indonesia saat ini, menetapkan kurikulum 2013 sebagai kurikulum yang dapat mempersiapkan perubahan dalam 
era globalisasi. Menurut Anwar (2014: 98) objek yang menjadi pembelajaran dalam penataan dan penyempurnaan kurikulum 2013 ini lebih menekankan pada fenomena alam, fenomena seni dan fenomena budaya. Melalui pendekatan tersebut siswa diharapkan untuk memiliki kompetensi sikap, keterampilan dan pengetahuan yang lebih baik. Masalah-masalah rumit di berbagai bidang kehidupan di abad 21 ini, menuntut setiap individu agar dapat memiliki ketangguhan dan berpikir kritis dalam menganalisis, evaluasi dan mencari penyelesaian alternatif atas masalah yang dihadapi. Sehaferan dalam Ejin (2016:66) menjelaskan berpikir kritis adalah kemampuan belajar yang harus diajarkan pada siswa karena kemampuan ini sangat diperlukan dalam kehidupan. Berpikir kritis siswa adalah salah satu kecakapan hidup yang perlu dilatihkan sejak sekolah dasar untuk memberikan bekal yang baik untuk kehidupan siswa.

Keterampilan berpikir kritis merupakan salah satu hal penting dalam proses memecahkan suatu permasalahan. Menurut Rahayuni (2016: 134) keterampilan berpikir kritis dapat dilatih melalui pelajaran IPA atau disiplin ilmu lain dengan pembelajaran yang berpusat pada peserta didik. Badarudin (2018) mengemukakan bahwa Ilmu Pengetahuan Alam (IPA) sebagai salah satu mata pelajaran di SD yang memberikan kesempatan kepada anak untuk mengembangkan kemampuan berpikirnya dalam menjelaskan suatu masalah dan melatihkan keterampilan.

Berdasarkan hasil refleksi dan evaluasi pembelajaran yang dilakukan oleh guru kelas IVB

SD Negeri 1 Tinggarjaya, diperoleh beberapa faktor yang dapat diasumsikan sebagai penyebab rendahnya keterampilan berpikir kritis peserta didik, diantaranya pembelajaran yang masih berpusat pada guru hal ini menjelaskan bahwa guru masih mendominasi pembelajaran dan proses pembelajaran masih bertujuan transfer pengetahuan, belum mengajak peserta didik berpikir sehingga permasalahan berpikir kritis peserta didik terjadi. Adapun ciri-ciri keterampilan berpikir kritis peserta didik rendah yaitu guru menjelaskan bahwa peserta didik masih malu untuk melakukan presentasi dalam penyampaian gagasan baik individu maupun kelompok, dalam kegiatan presentasi keikutsertaan peserta didik lain untuk bertanya dan menanggapi masih terlalu pasif hal ini dikarenakan kurang fokusnya peserta didik terhadap proses presentasi yang dilakukan oleh temannya, dalam proses pembelajaran guru memberikan permasalahan yang ditujukan kepada peserta didik namun peserta didik masih sering mengalami kesulitan untuk menemukan solusi dan memecahkan permasalahan yang sudah diberikan oleh guru hal ini ditujukan dengan masih banyak keikutsertaan guru dalam proses mencari solusi sehingga peserta didik masih banyak bergantung pada guru.

Kondisi itu terjadi dan dapat diamati dengan jelas terutama pada pembelajaran IPA. Jika hal ini tidak segera diperbaiki, maka literasi sains peserta didik akan rendah. Literasi sains merupakan salah satu hal yang penting untuk dipelajari, Purwami dalam Adiwiguna dkk (2019) menjelaskan bahwa pendidikan sains di sekolah diharapkan membentuk peserta didik yang memiliki literasi sains tinggi demi mempersiapkan warga yang bertanggung jawab dan kepekaan terhadap masalah di sekitar kehidupan mereka dan menjadi kunci kompetensi dalam menyiapkan generasi yang mampu menggunakan ilmu pengetahuan dan informasi untuk menghadapi tantangan hidup.

Berdasarkan hasil diskusi dengan guru, maka peneliti berkolaborasi untuk melakukan upaya meningkatkan kemampuan berpikir kritis siswa melalui penerapan Problem Based Learning (PBL). PBL merupakan pembelajaran yang berdasarkan pada permasalahan. Permasalahan yang ada, berasal dari kenyataan disekitar. Menurut Arends dalam Warsono dan Haryanto (2013:147) pada esensinya pembelajaran berbasis masalah adalah model pembelajaran yang berlandaskan konstruktivisme dan mengakomodasikan keterlibatan peserta didik dalam belajar serta terlibat dalam pemecahan masalah yang kontekstual. Menurut Yuyun (2017:58) guru sebaiknya menerapkan pembelajaran sesuai karakteristik siswa SD serta menekankan aktivitas peserta didik baik aktivitas mengevaluasi dan menganalisis apa yang dipelajari.

Model PBL diharapkan dapat menjadi solusi bagi guru dalam meningkatkan keterampilan berpikir kritis peserta didik. Beberapa penelitian yang pernah dilakukan tentang PBL seperti dalam penelitian Anindyta dan Suwarjo (2014) yang menemukan bahwa PBL berpengaruh secara positif terhadap keterampilan berpikir kritis dan regulasi siswa. Model PBL 
juga dapat melatih penguasaan konsep dan keterampilan berpikir kritis siswa SD (Ejin, 2016). Produk pengembangan alat pembelajaran tematik terintegrasi berdasarkan PBL yang efektif digunakan untuk pembelajaran di kelas empat (Sabdaningtyas dan Ambarita, 2019). Model PBL dalam pembelajaan IPA efektif meningkatkan keterampilan berpikir kritis dan interpersonal kelas lima (Amarullah dan Suwarjo, 2018). Hasil analisis meta menunjukkan bahwa model PBL mampu meningkatkan keterampilan berpikir kritis siswa yang terendah $2,87 \%$ sampai yang tertinggi $33,56 \%$ dengan peningkatan yang signifikan sebesar $12,73 \%$ (Anugrahani, 2018). Kelebihan model PBL menurut Warsono dan Haryanto (2013:152) yaitu siswa akan terbiasa menghadapi (problem posing) dan merasa tertantang untuk menyelesaikan masalah tidak hanya terkait dengan pembelajaran dalam kelas, tetapi juga menghadapi masalah yang ada dalam kehidupan sehari-hari (real word), memupuk solidaritas sosial dengan terbiasa berdiskusi dengan teman-teman sekelompok kemudian berdiskusi dengan teman-teman sekelasnya, makin mengakrabkan guru dengan siswa, karena ada kemungkinan suatu masalah harus diselesaikan siswa melalui eksperimen, hal ini juga akan membiasakan siswa dalam menerapkan metode eksperimen. Sehingga dengan keunggulan tersebut model pembelajaran ini dapat membangun keterampilan berpikir peserta didik.

Berdasarkan uarain di atas, maka peneliti berkolaborasi dengan guru melakukan upaya untuk meningkatkan keterampilan berpikir kritis siswa melalui penerapan PBL dalam pembelajaran, melalui sebuah penelitian yang berjudul "Upaya Meningkatkan Keterampilan Berpikir Kritis Peserta Didik melalui Penerapan Model PBL berbasis literasi sains tema 7 Indahnya Keragaman di Negeriku di kelas IVB SD Negeri 1 Tinggarjaya". Adapun inovasi dalam penelitian yang akan dilakukan yaitu, literasi sains sehingga model pembelajaran yang akan digunakan, adalah model PBL berbasis literasi sains. Dengan inovasi tersebut akan membantu peserta didik dalam meningkatkan literasi sains dan menemukan informasi untuk memecahkan suatu permasalahan.

\section{Metode Penelitian}

Jenis penelitian yang digunakan adalah Penelitian Tindakan Kelas (PTK). Penelitian tindakan kelas Menurut Kemmis dan Mctaggart dalam Huda, (2015: 5) adalah salah satu bentuk penyelidikan refleksi-diri yang dilaksasnakan oleh para partisipan dalam situasi-situasi sosial (termasuk pendidikan) untuk meningkatkan rasionalitas dan keadilan dalam (a) praktikpraktik sosial dan pendidikan mereka sendiri, (b) pemahaman mereka tentang praktik-praktik ini, dan (c) situasi-situasi yang melingkupi pelaksanaan praktik-praktik tersebut.

Penelitian ini dilakukan di kelas IVB SDN 1 Tinggarjaya yang terletak di Jalan Raya Tinggarjaya, Desa Tinggarjaya, Kecamatan Jatilawang, Kabupaten Banyumas pada tema 7 Indahnya Keragaman di Negeriku. Subyek penelitian ini adalah peserta didik kelas IVB yang berjumlah 11 peserta didik laki-laki dan 15 peserta didik perempuan.

Instrumen yang digunakan dalam penelitian ini adalah lembar observasi aktivitas guru, lembar aktivtias peserta didik, kisi-kisi soal kemampuan berpikirir kritis dan lembar soal kemampuan berpikir kritis. Teknik pengumpulan data penelitian ini menggunakan teknik tes dan teknik non tes. Teknik tes berupa tes uraian untuk mengukur Keterampilan berpikir kritis. Teknik non tes berupa dari obervasi dan dokumentasi pembelajaran dengan model PBL. Analisis data yang akan diperoleh meliputi analisis kemampuan berpikir kritis peserta didik, analisis lembar observasi guru dan lembar observasi peserta didik. Prosedur penelitian ini menggunakan model Kemmis dan Mc. Taggart yang terdiri dari empat tahapan yaitu tahap tahap perencanaan (planning), tindakan (action), observasi (observation), dan refleksi (reflection).

\section{Hasil dan Pembahasan}

Penelitian ini menerapkan model PBL berbasis literasi sains yang bertujuan untuk meningkatkan keterampilan berpikir kritis peserta didik SDN 1 Tinggarjaya. Hasil penelitian disini menjelaskan hasil dari 3 siklus, yang setiap siklusnya terdiri dari 2 pertemuan menggunakan model PBL berbasis literasi sains. Adapun hasil penelitian ini adalah sebagai berikut: 
1. Perencanaan Tindakan (Planning)

Tahap ini peneliti merancang pembelajaran dengan mempersiapkan pokok bahasan yang digunakan dalam penelitian untuk membuat perencanaan pembelajaran seperti RPP, Standar Kompetensi (SK), Kompetensi dasar (KD), Menyiapkan model PBL berbasis literasi sains, membuat lembar kerja peserta didik, menyusun kisi-kisi soal kemampuan berpikir kritis dan lembar soal kemampuan berpikir kritis, dan menyiapkan literasi sains.

2. Pelaksanaan Tindakan

Pada pelaksanan tindakan menggunakan fase-fase dari model problem based leraning yaitu:

Fase 1 memberikan orientasi tentang permasalahan kepada peserta didik

Fase 2 mengorganisasikan peserta didik untuk meneliti

Fase 3 membantu investigasi kelompok guru membimbing peserta didik

Fase 4 mengembangkan dan mempresentasikan

Fase 5 menganalisis dan mengevaluasi proses pemecahan masalah

3. Observasi

Pada tahap observasi merupakan tahap dimana lembar observasi aktivitas guru, lembar observasi aktivitas peserta didik dan soal keterampilan berpikir kritis peserta didik diisi dan diseskripsikan.

4. Refleksi

Pada kegiatan refleksi, guru dan penulis mendiskusikan tentang hal yang perlu diperbaiki untuk dapat melanjutkan ke siklus berikutnya agar kualitas pembelajaran menjadi lebih baik.

Setelah diterapkan tahapan-tahapan diatas, selama 3 siklus diperoleh hasil peningkatan keterampilan berpikir kritis peserta didik sesuai dalam Tabel 1. Untuk mengukur keterampilan berpikir kritis siswa, dilakukan tes uraian berjumlah 5 butir soal yang disesuaikan dengan indikator keterampilan berpikir kritis. Indikator berpikir kritis yang digunakan dalam penelitian ini adalah: 1) memberikan penjelasan sederhana, 2) membangun keterampilan dasar, 3) membuat inverensi/ menyimpulkan, 4) memberikan penjelasan lebih lanjut, 5) mengatur strategi dan taktik Susanto (2015: 125). Berikut hasil rekapitulasi perolehan skor rata-rata kemampuan berpikir kritis peserta didik setiap indikator:

Tabel 1. Nilai Tes Keterampilan Berpikir Kritis Tiap Indikator

\begin{tabular}{llccc}
\hline No. & $\begin{array}{c}\text { Indikator Keterampilan Berpikir } \\
\text { Kritis }\end{array}$ & Siklus 1 & Siklus 2 & Siklus 3 \\
\hline 1. & Memberikan penjelasan sederhana & 2,2 & 2,6 & 3,77 \\
2. & Membangun keterampilan dasar & 2,07 & 2,28 & 3,28 \\
3. & Membuat inversi/menyimpulkan & 1,86 & 2,99 & 2,73 \\
4. & Memberikan penjelasan lebih lanjut & 2,33 & 2,34 & 3,22 \\
5. & Mengatur strategi dan taktik & 2,58 & 2,68 & 2,24 \\
& Jumlah & 19,59 & 25,79 & 30,52 \\
& Rata-Rata & 1,95 & 2,57 & 3,04 \\
& Kriteria & Tidak & Kurang & Baik \\
& Baik & Baik & \\
\hline
\end{tabular}

Berdasarkan Tabel 1 dapat jelaskan adanya hasil tes keterampilan berpikir kritis tiap indikator, yaitu 1) memberikan penjelasan sederhana, pada siklus 1 memperoleh skor rata-rata 2,2 dengan kriteria tidak baik, siklus 2 2,6 dengan kriteria kurang baik dan pada siklus 3 3,77 dengan kriteria sangat baik. Hal itu membuktikan bahwa indikator 1 mengalami kenaikan. Indikator 2) yaitu membangun keterampilan dasar, pada siklus 1 memperoleh skor rata-rata 2,07 dengan kriteria tidak baik, pada siklus 2 memperoleh skor rata-rata 2,28 dengan kriteria kurang baik, dan pada siklus 3 memperoleh skor rata-rata 3,28 dengan kriteria baik. Hal itu menunjukkan terdapat kenaikan pada setiap siklusnya. Indikator 3) yaitu membuat inversi/ menyimpulkan, pada siklus 1 memperoleh skor rata-rata 1,86 dengan kriteria tidak baik, pada siklus 2 memperoleh 
skor rata-rata 2,99 dengan kriteria kurang baik, dan pada siklus 3 memperoleh skor rata-rata 2,73 dengan kriteria kurang baik. Hal ini menunjukkan bahwa terdapan kenaikan dari siklus 1 ke siklus 2 dan terdapat penurunan dari siklus 2 kesiklus 3. Indikator 4) yaitu memberikan penjelasan lebih lanjut, pada siklus 1 memperoleh skor rata-rata 2,33 dengan kriteria kurang baik, pada siklus 2 memperoleh skor rata-rata 2,34 dengan kriteria kurang baik dan pada siklus 3 memperoleh skor rata-rata 3,22 dengan kriteria baik. Hal itu menunjukkan bahwa terdapat kenaikan pada setiap siklusnya. Indikator 5) yaitu mengatur strategi dan taktik, pada siklus 1 memperoleh skor rata-rata 2,58 dengan kriteria kurang baik, pada siklus 2 memperoleh skor rata-rata 2,68 dengan kriteria kurang baik dan pada siklus 3 memperoleh skor rata-rata 2,24 dengan kriteria kurang baik. Hal ini menunjukkan bahwa terdapat kenaikan pada siklus 1 ke siklus 2 dan terdapat penurunan pada siklus 2 ke siklus 3 .

Temuan dalam penelitian ini yaitu terdapat peningkatan yang signifikan terjadi pada indikator 1 dengan peningkatan dari siklus 1 ke siklus 2 sebesar 0,4 dan dari siklus 2 ke siklus 3 sebesar 1,17, terdapat kenaikan juga pada indikator 2 dengan peningkatan dari siklus 1 ke siklus 2 sebesar 0,21 dan dari siklus 2 ke siklus 3 sebesar 1, dan yang terakhir terdapat kenaikan pada indikator 4 dari siklus 1 ke siklus 2 sebesar 0,01 dan dari siklus 2 ke siklus 3 sebesar 0,88 . Adapun penurunan yang signifikan terjadi pada indikator 3 dari siklus 2 ke siklus 3 sebesar 0,26. Terdapat penurunan juga pada indikator siklus 5 dari siklus 2 ke siklus 3 sebesar 0,44. Penyebab turunnya indikator 3 dan indikator 5 dikarenakan peserta didik pada saat proses pembelajaran berlangsung masih bermain sendiri dan tidak memperhatikan penjelasan dari guru sehingga peserta didik belum dapat menyimpulkan suatu permasalahan dan belum dapat mengatur strategi dan taktik yang baik untuk menyelesaikan suatu permasalahan. Guru sudah melakukan upaya dengan menegur peserta didik yang sedang bermain sendiri dan merangsang peserta didik untuk aktif dalam proses pembelajaran namun peserta didik masih menghiraukannya.

Secara umum penggunaan model PBL berbasis literasi sains memberikan dapat yang baik bagi proses pembelajaran. Hal ini dibuktikan pada meningkatnya keterampilan berpikir kritis peserta didik dengan memecahkan suatu permasalahan. Peningkatan keterampilan berpikir kritis peserta didik kelas IV SDN 1 Tinggarjaya pada siklus 1, siklus 2 dan siklus 3, dapat disajikan pada Tebel 2 berikut:

\section{Tabel 2. Hasil Keterampilan Berpikir Kritis Peserta Didik untuk Tiap Siklus}

\begin{tabular}{cccc}
\hline Siklus & Skor & Rata-Rata & Kriteria \\
\hline Siklus 1 & 19,59 & 1,95 & Tidak Baik \\
Siklus 2 & 25,79 & 2,57 & Kurang Baik \\
Siklus 3 & 30,52 & 3,04 & Baik \\
\hline
\end{tabular}

Berdasarkan Tabel 2 di atas, dapat diketahui bahwa terjadi peningkatan keterampilan berpikir kritis peserta didik dari siklus 1 ke siklus 2 sebesar 6, dan terdapat peningkatan juga dari siklus 2 ke siklus 3 sebesar 4,73. Peningkatan tersebut karena penggunaan model problem based learning berbasis literasi sains yang telah dilakukan mampu meningkatkan berpikir kritis peserta didik secara lebih mendalam mengenai permasalahan yang telah diberikan oleh guru kepada peserta didik sehingga mampu mencari solusi untuk memecahkan permasalahan tersebut. Hal ini sejalan dengan penelitian relevan menurut beberapa peneliti yaitu Anindyta dan Suwarjo (2014), Ejin (2016), Sabdaningtyas dan Ambarita (2019), Amarullah dan Suwarjo (2018), Anugrahani (2018) mengemukakan bahwa model PBL dapat meningkatkan keterampilan berpikir kritis peserta didik.

\section{Kesimpulan}

Berdasarkan hasil Penelitian Tindakan Kelas yang telah dilakukan selama 3 siklus, dapat diperoleh kesimpulan bahwa model PBL berbasis literasi dapat meningkatkan keterampilan berpikir kritis peserta didik di kelas IVB SD Negeri 1 Tinggarjaya. Terdapat peningkatan yang signifikan terjadi pada indikator 1 dengan peningkatan dari siklus 1 ke siklus 2 sebesar 0,4 dan 
dari siklus 2 ke siklus 3 sebesar 1,17, terdapat kenaikan juga pada indikator 2 dengan peningkatan dari siklus 1 ke siklus 2 sebesar 0,21 dan dari siklus 2 ke siklus 3 sebesar 1 , dan yang terakhir terdapat kenaikan pada indikator 4 dari siklus 1 ke siklus 2 sebesar 0,01 dan dari siklus 2 ke siklus 3 sebesar 0,88 . Adapun penurunan yang signifikan terjadi pada indikator 3 dari siklus 2 ke siklus 3 sebesar 0,26 . Terdapat penurunan juga pada indikator 5 dari siklus 2 ke siklus 3 sebesar 0,44 . Berdasarkan pada kesimpulan tersebut peneliti menyadari sepenuhnya bahwa terdapat keterbatasan baik waktu dan tenaga serta kemampuan yang dimiliki oleh peneliti sendiri. Terdapat suatu hal yang harus diperhatikan dalam melaksanakan suatu penelitian pembelajaran dikelas, yaitu guru perlu mengembangkan keterampilan berpikir kritis peserta didik dengan menerapkan model problem based learning berbasis literasi sains pada tema yang berbeda dan mengaitkannya dengan materi yang sedang dipelajari dalam kehidupan nyata agar peserta didik dapat mengembangkan keterampilan berpikir kritisnya.

\section{Daftar Pustaka}

Adiwiguna, S., Dantes, N., \& Gunamantha, M. (2019). Pengaruh Model Problem Based Learning (PBL) berorientasi STEM terhadap Kemampuan Berpikir Kritis dan Literasi Sains Siswa Kelas V SD di Gugus I Gusti Ketut Pudja. Pendasi: Jurnal Pendidikan Dasar Indonesia, 3(2), 94-103.

Amrullah, K., \& Suwarjo, S. (2018). The effectiveness of the cooperative problem-based learning in improving the elementary school students' critical thinking skills and interpersonal intelligence. Jurnal Prima Edukasia, 6(1), 66-77.

Anindyta, P., \& Suwarjo, S. (2014). Pengaruh problem based learning terhadap keterampilan berpikir kritis dan regulasi diri siswa kelas V. Jurnal Prima Edukasia, 2(2), 209-222.

Anugraheni, I. (2018). Meta Analisis Model Pembelajaran Problem Based Learning dalam Meningkatkan Keterampilan Berpikir Kritis di Sekolah Dasar [A Meta-analysis of Problem-Based Learning Models in Increasing Critical Thinking Skills in Elementary Schools]. Polyglot: Jurnal Ilmiah, 14(1), 9-18.

Anwar, R. (2014). Hal-hal yang mendasari penerapan Kurikulum 2013. Humaniora, 5(1), 97106.

Badarudin, (2018). Peningkatan Sikap Peduli Lingkungan dan Prestasi Belajar IPA menggunakan Model Problem Based Learning Berbasis Literasi pada Subtema Lingkungan Tempat Tinggalku di Kelas IV MI Muhammadiyah Kramat. JPDI (Jurnal Pendidikan Dasar Indonesia), 3(2), 50-56.

Ejin, S. (2016). Pengaruh Model Problem Based Learning (PBL Terhadap Pemahaman Konsep dan Keterampilan Berpikir Kritis Siswa Kelas IV SDN Jambu Hilir Baluti 2 Pada Mata Pelajaran Ilmu Pengetahuan Alam. Jurnal Pendidikan (Teori dan Praktik), 1(1), 66-72.

Haryanti, Y. D. (2017). Model Problem Based Learning Membangun Kemampuan Berpikir Kritis Siswa Sekolah Dasar. Jurnal Cakrawala Pendas, 3(2).

Huda, M. (2015). Penelitian Tindakan Kelas Teori dan Praktik. Yogyakarta: Pustaka Pelajar.

Rahayuni, G. (2016). Hubungan keterampilan berpikir kritis dan literasi sains pada pembelajaran IPA terpadu dengan model PBM dan STM. Jurnal penelitian dan Pembelajaran IPA, 2(2), 131-146.

Sabdaningtyas, L., \& Ambarita, A. (2019). The Development of Integrative Thematic Learning Tools Based on Problem Based Learning to Improve Critical Thinking of Students in Fourth Grade in Elementary School. Jurnal education and pratice, 10(30), 33-40

Warsono, H. (2013). Pembelajaran Aktif. Bandung: PT Remaja rosdakarya. 